\title{
MESOPHASE MICROSPHERES FROM DISTILLATION AND THERMAL TREATMENT OF COAL TAR
}

\author{
Rocio Martinez-Flores ${ }^{1}$, J. E. Camporredondo-Saucedo ${ }^{2}$, H.A. Moreno-C ${ }^{3}$, \\ G. Gonzalez-Zamarripa 4 , M. Corona-Romo ${ }^{1}$, Witold Brostow ${ }^{5, *}$, \\ Haley E. Hagg Lobland 5
}

https://doi.org/10.23939/chcht11.02.230

\begin{abstract}
We have investigated the formation of mesophase carbon microbeads in tar pitch generated by the coal coking in a steelmaking plant. Pitches were obtained at different distillation temperatures $(643,673$ and $723 \mathrm{~K}$ ). The distilled samples were then thermally treated in nitrogen atmosphere either at $723 \mathrm{~K}$ for $8 \mathrm{~h}(\mathrm{~T} 1)$ for at $703 \mathrm{~K}$ for $4 \mathrm{~h}(\mathrm{~T} 2)$. A new phase appears, seen in optical microscopy with a polarizing filter. Samples subjected to the T1 thermal treatment were found to form a discontinuous fluid phase distinct from the main phase. Formation of mesophase carbon microbeads is seen also in samples subjected to the T2 treatment, with the particle diameters from 30 to $60 \mu \mathrm{m}$. The microbeads can be used as precursors for the synthesis of graphitic materials.
\end{abstract}

Keywords: mesophase carbon microspheres, coal tar, graphitic materials.

\section{Introduction}

Coal tar is a by-product of thermal degradation of coal. The objective of the degradation process is either carbonization to obtain coke or gasification to obtain the so-called coal gas as well. Distillation of coal tar leaves behind coal tar pitch (CTP), a thick black liquid with

\footnotetext{
${ }^{1}$ Doctorado en Ciencia y Tecnología de Materiales, Facultad de Ciencias Químicas, Universidad Autónoma de Coahuila, Blvd. V. Carranza S/N, Saltillo, Coah. 25280, Mexico

${ }^{2}$ Facultad de Ingeniería Mecánica y Eléctrica, Universidad Autónoma de Coahuila, Calle Barranquilla S/N, Col. Guadalupe, Monclova, Coah. 25750, Mexico

${ }^{3}$ Tecnológico Nacional de México - Instituto Tecnológico de la Laguna, Blvd. Revolucion y Czda. Cuauhtemoc S/N, Torreon, Coah., Mexico ${ }^{4}$ Universidad Politécnica de Monclova-Frontera, Av. Las Granjas 602, Monclova, Coah. 25720, Mexico

${ }_{5}^{5}$ LAPOM, Department of Materials Science and Engineering, University of North Texas, 3940 North Elm Street, Denton, TX 76207, USA

*wkbrostow@gmail.com

(C) Martinez-Flores R., Camporredondo-Saucedo J., Moreno-C H., Gonzalez-Zamarripa G., Corona-Romo M., Brostow W., Hagg Lobland H., 2017
}

viscosity even higher than coal tar. CTP is a complex mixture of polyaromatic hydrocarbons [1,2]. Problems of separation into components are somewhat similar as in petroleum [3]. A widely used characterization parameter based on the elemental analysis is the $\mathrm{C} / \mathrm{H}$ ratio. This ratio is related to the structure of the pitch components. CTP is widely used to prepare carbon materials due to its relatively low cost, availability and high carbon yield (CY) [4]. Due to the chemical complexity of the pitch, detailed characterization is essential to assess possible applications [5]. In industries where pitches are used, and/or prepared, it is convenient to arrange a routine characterization procedure that is as simple as possible.

Tar pitches contain dispersed carbonaceous particles generated in the coke oven. The gases, getting into the tar, carry these particles. In the pitch, the particles are insoluble, even in the presence of powerful solvents such as quinoline. In industrial applications, the common practice is to determine the fraction of the pitch insoluble in toluene (TI) and in quinoline (QI), as well as the pitch softening temperature (SP) [6]. The term "primary", such as in PQI, pertains to insoluble material from the primary coal conversion process. This is in contrast to the secondary QI (SQI) that pertains to the insoluble fraction after pitch thermal treatment [7-9].

The pitch softening temperature is closely associated with density and balance of the light/heavy compounds in it. As expected, the higher the softening point, the more that balance is shifted towards the heavy compounds. The structural composition and texture of TI and QI substances contained in the CTP, as a raw material for advanced carbon materials, have both scientific and practical interest. They also provide valuable information about the behavior during the carbonization of the CTP fractions, the time evolution of the thermo-chemical processes during the coking, the influence on the mesophase formation with the development of isotropic and anisotropic coke textures, and obviously on the potential applications [10]. Mesophases can be prepared from soft coal tar, petroleum residues and from pure aromatic compounds with a Lewis acid [11-13]. 
When coal pitches or petroleum derived pitches are heated to temperatures over $650 \mathrm{~K}$, anisotropic spheres of a mesophase appear from the isotropic matrix [14]. Their coalescence progress generates bigger spheres resulting in a wide distribution of sphere sizes when coalescence occurs at random. In order to produce mesophase carbon microbeads (MCMBs), the coalescence must be stopped before the spheres are transformed into a continuous bulk mesophase [15]. Three stages are involved in the mesophase formation mechanism: nucleation, growth, and coalescence. The wide distribution of sphere sizes is attributed to an extended period of nucleation and/or high coalescence frequency $[16,17]$.

Primary quinoline insoluble particles have been studied by microscopy already in 1983 by Kremer and Cukier [18]. PQIs might be able to overcome the highenergy barrier of a new mesophase formation and in this way decrease the activation energy of MCMBs formation. It appears that the QI particles serve as nuclei for the MCMBs growth [19].

Applications of carbon-containing materials often take advantage of the flexible coordination chemistry of carbon atoms, which allow wide possibilities of tridimensional structures due to their ability to bind atoms of different elements [20]. MCMBs are recognized as optimal precursors of carbon materials of high density and high strength [21-24].

As expected, when MCMBs are prepared from CTP containing PQI and QI, the development of the mesophase and the microstructure of resulting MCMBs depend on the quality of the precursors and additives, as well as on the conditions of the carbonization process [2530]. In this situation, the aim of our work was obtaining MCMBs from the coal tar generated in an industrial process, keeping in mind the potential applications of these particles.

\section{Experimental}

We have used coal tar generated as a byproduct of the coking process in an industrial steelmaking plant. According to the supplier, its $\mathrm{QI}=3.0 \%$ and $\mathrm{TI}=4.3 \%$. Nitrogen industrial grade gas was used for thermal treatment and pyrolysis. For solubility tests, toluene and $\mathrm{N}$-methyl-2pyrrolidone (NMP) ACS grade reagents were used.

Tar distillation was carried out using a Koehler model K45200 Distillation Apparatus, following the ASTM D86 standard procedure. Samples of $100 \mathrm{ml}$ of tar were treated, at temperatures of $643 \mathrm{~K}$, called DES370 in the following), $673 \mathrm{~K}$ (called DES400) and $723 \mathrm{~K}$ (called DES450).

Thermal treatment of pitches was conducted in a thermally insulated heating reactor, with a controlled nitrogen flow of $0.21 \cdot \mathrm{min}^{-1}$. Table 1 summarizes experimental conditions of distillation and thermal treatments of the pitches.

Content of carbon, hydrogen, nitrogen and sulphur in samples was determined with a LECO-CHNS-932 elemental analyzer at $1323 \mathrm{~K}$, using $1 \mathrm{mg}$ samples. The oxygen content was determined in a LECO VTF-900 graphite furnace coupled to the elemental analyzer.

The softening point measurements of the pitches were made using a Mettler Toledo FP90 equipment, according to the ASTM D3104 method.

The toluene solubility tests of toluene insoluble particles (TI) of the pitches were conducted according to the ASTM D4312-95A method. Content of insolubles in $N$-methyl-2-pyrrolidone (NMPI) was determined by a similar procedure.

Pyrolysis of samples was performed at $1623 \mathrm{~K}$, with a flow of $225 \mathrm{ml} \cdot \mathrm{min}^{-1}$ of nitrogen. The carbon yield was determined according to the ASTM D4715 method (Alcan procedure).

Thermogravimetric analysis (TGA) of the pitches was performed by a Perkin-Elmer TGA7 apparatus. The TGA technique is well explained by Menard [31] and also discussed in a textbook by some of us [32].

After heat treatments, the resulting pitch samples were grinded and sieved at a particle size less than $0.4 \mathrm{~mm}$ and then embedded into an epoxy resin. The polished samples were examined by a Zeiss Axioplan microscope with a polarizing filter. For the identification of the predominant microstructures, objectives of $20 \mathrm{X}, 50 \mathrm{X}$ or 100X immersed in oil were used. For brevity, only 20X magnifications are presented here. Micrographs were obtained using a Leica model DC100 photographic camera.

\section{Results and Discussion}

\subsection{Elemental Composition}

Table 2 presents the elemental compositions and the $\mathrm{C} / \mathrm{H}$ ratios of our samples. Marked trends are observed for $\mathrm{C}, \mathrm{H}, \mathrm{O}$ and the $\mathrm{C} / \mathrm{H}$ ratio. Lower boiling fractions contain more hydrogen and oxygen. Therefore, as the distillation temperature is increased, concentration of $\mathrm{C}$ increases, while concentrations of oxygen and hydrogen decrease. The $\mathrm{C} / \mathrm{H}$ ratio increases along with the distillation temperature.

\subsection{Softening Point}

In Table 3 we show the results of the softening point and solubility tests. The sample distilled at $723 \mathrm{~K}$ has the highest softening point. It is expected that distillation to a higher temperature produces more higher molecular weight compounds. In function of the softening point, pitches are classified as either binding or impregnating ones. Based on this classification scheme, our samples are impregnating. 
Experimental conditions of distillation and thermal treatments of the pitches

\begin{tabular}{|c|c|c|c|}
\hline \multirow{2}{*}{ Sample designation } & \multirow{2}{*}{ Distillation temperature, $\mathrm{K}$} & \multicolumn{2}{|c|}{ Thermal treatment } \\
\cline { 3 - 4 } & & $T_{1}, 723 \mathrm{~K}, 8 \mathrm{~h}$ & $T_{2}, 703 \mathrm{~K}, 4 \mathrm{~h}$ \\
\hline CTP & - & - & $\mathrm{CTPT} 2$ \\
\hline DES370 & 643 & DES370T1 & - \\
\hline DES400 & 673 & DES400T1 & DES400T2 \\
\hline DES450 & 723 & DES450T1 & DES450T2 \\
\hline
\end{tabular}

Table 2

Elemental composition of samples

\begin{tabular}{|c|c|c|c|c|}
\hline Element, \% & CTP & DES370 & DES400 & DES450 \\
\hline $\mathrm{C}$ & 91.0 & 92.1 & 92.8 & 93.7 \\
\hline $\mathrm{H}$ & 5.10 & 4.47 & 4.38 & 4.28 \\
\hline $\mathrm{N}$ & 0.74 & 0.71 & 0.73 & 0.74 \\
\hline $\mathrm{S}$ & 0.58 & 0.65 & 0.64 & 0.51 \\
\hline $\mathrm{O}$ & 2.39 & 0.89 & 0.55 & 0.52 \\
\hline $\mathrm{C} / \mathrm{H}$ & 1.50 & 1.73 & 1.78 & 1.84 \\
\hline
\end{tabular}

Table 3

Results for softening point and solubility tests

\begin{tabular}{|l|c|c|c|c|}
\hline \multicolumn{1}{|c|}{ Indices } & CTP & DES370 & DES400 & DES450 \\
\hline Softening point (SP), K & & 322 & 341 & 369 \\
\hline Toluene insoluble (TI), \% & 4.2 & 19.2 & 23.1 & 35.1 \\
\hline$N$-methyl-2-pyrrolidone (NMPI) insoluble, \% & & 8.6 & 9.7 & 23.0 \\
\hline Carbon yield (CY), \% & & 42 & 45 & 50 \\
\hline
\end{tabular}

Table 4

Comparison of TGA results with $\mathrm{CY}$ and with $\mathrm{C} / \mathrm{H}$ ratio

\begin{tabular}{|l|c|c|c|c|}
\hline \multicolumn{1}{|c|}{ Indices } & CTP & DES370 & DES400 & DES450 \\
\hline Carbon yield (CY), $\%$ & & 42 & 45 & 50 \\
\hline TGA, wt\% remaining & 20 & 28 & 31 & 42 \\
\hline C/H ratio & 1.50 & 1.73 & 1.78 & 1.84 \\
\hline
\end{tabular}

Two solvents with different polarity and extraction capacity were used, toluene and $\mathrm{N}$-methyl-2- pyrrolidone, as seen in Table 3 . The sample with the lowest solubility, that is DES450, also has the highest softening point $(369 \mathrm{~K})$, suggesting the existence of a relationship between these parameters. Insolubility increases with increasing distillation temperature. Thus, we expect formation of the most mesophase microspheres in the DES450 sample.

\subsection{Thermogravimetric Analysis Results}

We display the TGA results in Fig. 1. Except for CTP, significant weight losses begin at temperatures above $473 \mathrm{~K}$ and persist until approximately $823 \mathrm{~K}$. At temperatures higher than $873 \mathrm{~K}$, there is almost no change in the weight. CTP has the lowest thermal stability among the materials investigated, it refers to the entire temperature range up to $1273 \mathrm{~K}$. Thus, the carbonaceous

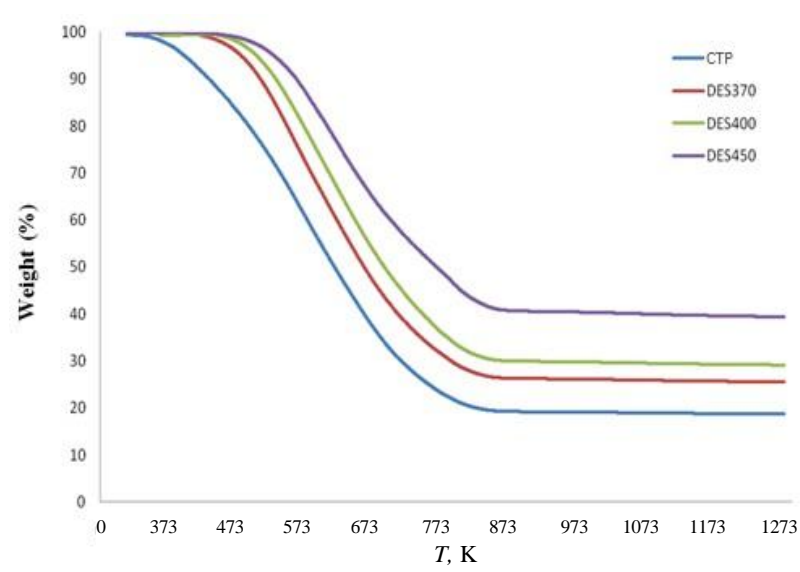

Fig. 1. TGA of CT and pitch degradation

residue at $1273 \mathrm{~K}$ is larger in the distilled samples than in the tar. Comparing the values of the weight percentage 
remaining at $1273 \mathrm{~K}$ in TGA and carbon yield at the temperature of $823 \mathrm{~K}$, we find that they behave symbatically; see Table 4.

\subsection{Optical Microscopy}

We reiterate that thermal treatments were applied to induce mesophase formation. Micrographs shown in Figs. $2 \mathrm{a}$ and $2 \mathrm{~b}$ both correspond to the DES370T1 sample, and both exhibit an anisotropic coke texture. The regions seen have different orientations that can be distinguished by different colors seen in polarized light. The flow domains lose their continuity because of the appearance of insoluble TI and NMPI 'islands'. The same phenomenon occurs for samples DES400T1 (Figs. 2c and 2d), and DES450T1 (Figs. 2e and 2f). In summary, T1 favors a fluid mesophase but not the MCMBs formation.

Samples DES400T2, DES450T2 and CTP were subjected to a thermal treatment at $703 \mathrm{~K}$ in nitrogen atmosphere for $4 \mathrm{~h}$. The corresponding micrographs are shown in Fig. 3. T2 treatment promotes MCMBs formation. Microspheres are dispersed in an isotropic matrix, along with TI and NMPI matter. The isotropic phase corresponds to the pink-brown area, while the anisotropic phase corresponds to spheres with different tonalities due to the effect of the polarized light. MCMB coalescence can be seen, particularly, in Figs. 3c and 3d for samples generated from DES450T2. MCMBs in Figs. $3 \mathrm{c}$ and $3 \mathrm{~d}$ have dimensions exceeding $50 \mu \mathrm{m}$. Thus, the
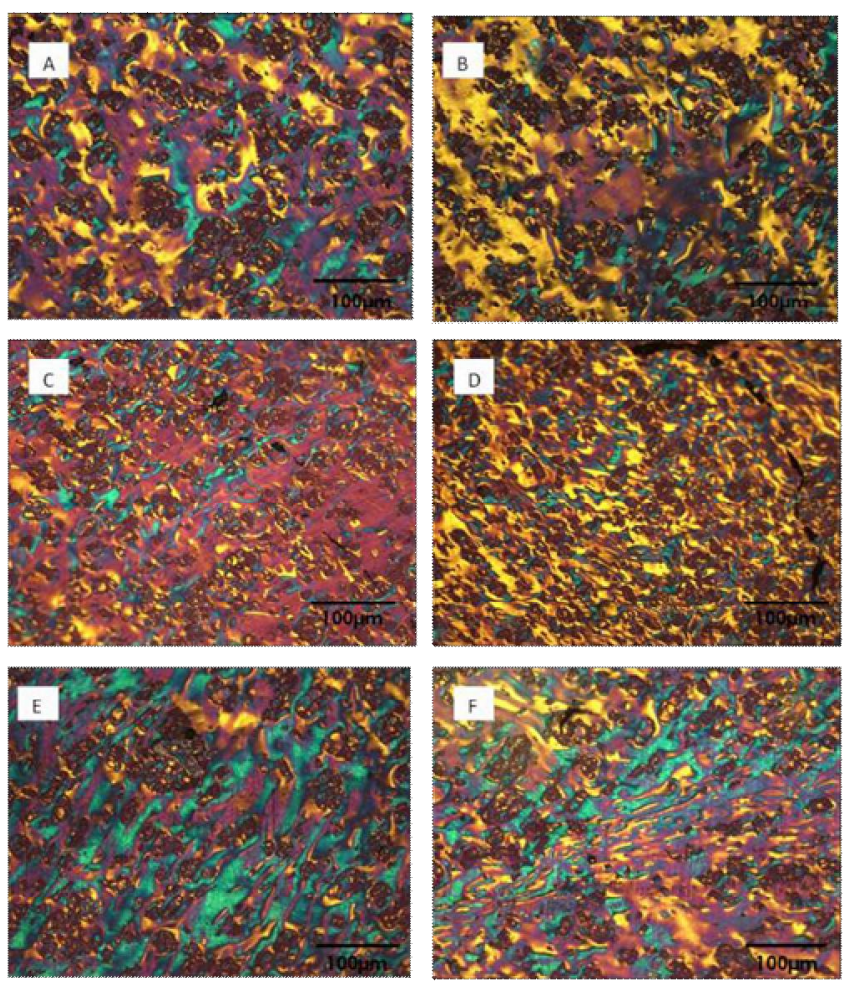

Fig. 2. 20X optical micrographs of DES370T1 (a, b); DES400T1 (c, d) and DES450T1 (e, f)
DES450T2 material provided MCMBs of a magnitude and distribution ideal for the synthesis of graphitic materials. Rapid carbonization involves formation of new beads; in DES450T2 the beads touch each other, their soft surfaces coalesce together, so that beads or spheres of large size are formed. In general, the rate of generation of MCMBs is related to the concentration of the precursor, in turn that concentration is a function of temperature. The coalescence process commences after termination of the generation process [16].

\section{Conclusions}

Tar distillation temperature has a significant effect on the pitch properties. As distillation temperature increases, the SP, TI, NMPI and CY increase - as does the aromaticity degree reflected in the $\mathrm{C} / \mathrm{H}$ ratio as well.

Temperature and thermal treatment duration play a critical role on the microstructures that are developed. There is evidence that the temperature of $723 \mathrm{~K}$, applied for $8 \mathrm{~h}$, contributes to the flow domain texture formation. The thermal treatment at a lower temperature and shorter duration $(703 \mathrm{~K}$ during $4 \mathrm{~h}$ ) promotes the MCMBs formation.

We observe the formation of MCMBs with diameters larger than $50 \mu \mathrm{m}$ when starting with CTP of industrial origin.
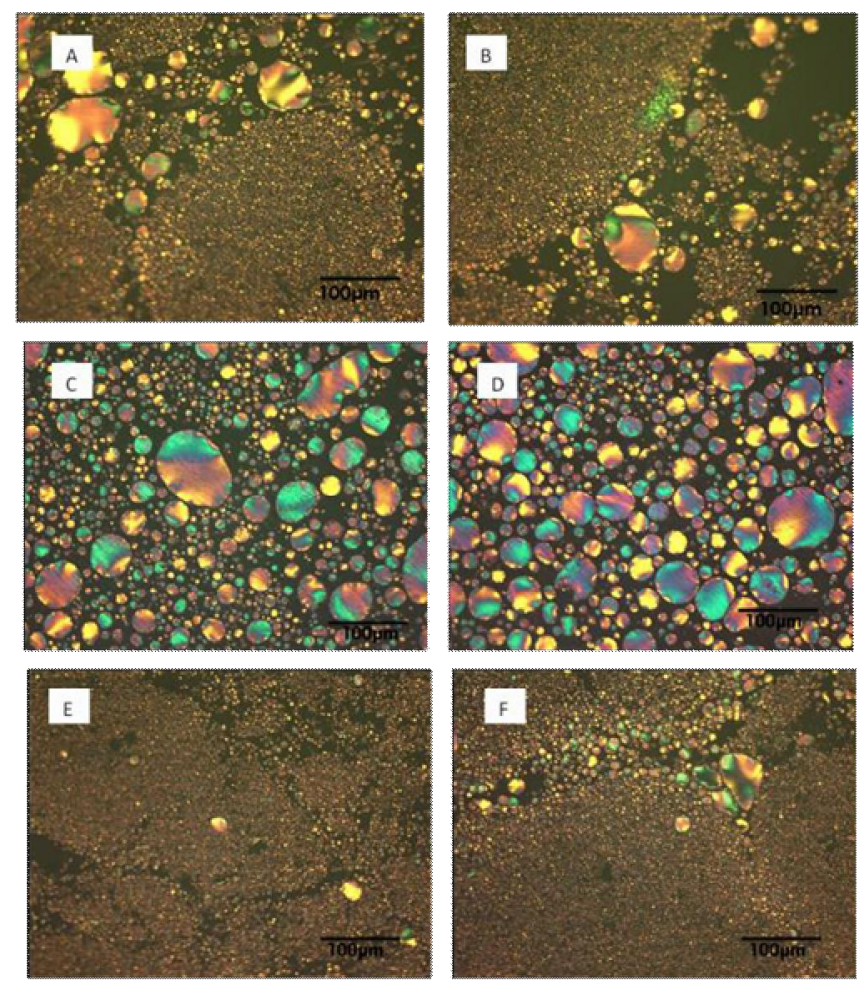

Fig. 3. 20X optical micrographs of DES400T2 (a, b); DES450T2 (c, d) and CTPT2 (e, f) 
Pitches obtained by distillation at $723 \mathrm{~K}$, and thermally treated at $703 \mathrm{~K}$ in nitrogen atmosphere during $4 \mathrm{~h}$ (DES450T2), produce MCMBs of a magnitude and distribution ideal to generate graphitic materials. As discussed by Lavin-Lopez and coworkers [33], graphite as well as graphene oxide can be used to produce graphene by simple and inexpensive methods.

Consider now our results from another point of view. Petroleum also contains heavy fractions that settle at the bottoms of the tanks during storage and transport. Therefore, Tertyshna and her colleagues developed a method of visbreaking, that is thermal degradation of those fractions, in their case at $713 \mathrm{~K}$ [34]. One thus reduces the viscosity with respect to the starting material by a factor between 6 and 10, one also reduces the density by up to $40 \%$, and obtains lower boiling fractions in an economical way. Production of petroleum involves a number of operations at different stages, developed and discussed in detail by Lucas and her coworkers [35-41]. A severe problem dealing with petroleum and also with coal is the presence of sulfur. Thus, methods of desulfurization are being developed, notably by Bratychak and coworkers $[42,43]$.

\section{Acknowledgments}

The authors wish to express their gratitude to the Altos Hornos de Mexico company, Monclova, Coahuila, Mexico, for sponsoring this research. We acknowledge Dr. Rosa María Menéndez of Instituto Nacional del Carbón, Oviedo, Spain, for the support and facilities provided for the execution of this project.

\section{References}

[1] Miller D., Lewis I., Chang C., Lewis, R.T.: US Patent WO 2009/142807 A2, 2009.

[2] Perez M., Granda M., Santamaría R. et al.: Fuel, 2004, 83, 1257. https://doi.org/10.1016/j.fuel.2003.11.012

[3] Areshidze G., Barbakadze K., Brostow W. et al.: Mater. Sci. Medziagotyra 2010, 16, 170.

[4] Cheng X., Zha Q., Li X., Yang X.: Fuel Process. Technol., 2008, 89, 1436. https://doi.org/10.1016/j.fuproc.2008.07.003

[5] Alcaniz-Monge J., Cazorla-Amoros D., Linares-Solano A.: Fuel, 2001, 80, 41. https://doi.org/10.1016/S0016-2361(00)00057-0

[6] Twigg A., Taylor R., Marsh K., Marr G.: Fuel, 1987, 66, 28. https://doi.org/10.1016/0016-2361(87)90207-9

[7] Rodriguez F.: Carbon, 1998, 36, 159. https://doi.org/10.1016/S0008-6223(97)00173-5

[8] Marsh H., Martínez M., Rodríguez F.: Carbon, 1999, 37, 363. https://doi.org/10.1016/S0008-6223(98)00205-X

[9] Jones S., Hildebrandt R., Hedlund M.: Influence of High-Sulfur Cokes on Anode Performance. Light Metals, the Metallurgical Society of AIME, Warrendalem 1979.

[10] Panaitescu C., Predeanu G.: Int. J .Coal Geol., 2007, 71, 448. https://doi.org/10.1016/j.coal.2006.11.003
[11] Mochida R., Kudo K., Fukuda N., Takeshita K.: Carbon, 1975, 13, 135. https://doi.org/10.1016/0008-6223(75)90270-5

[12] Yamaguchi C., Mondori J., Matsumoto A. et al.: Carbon, 1995, 33, 193. https://doi.org/10.1016/0008-6223(94)00127-L

[13] Fernandez A., Granda M., Bermejo J. et al.: Energ. Fuel., 1995, 12, 949. https://doi.org/10.1021/ef9800258

[14] Tascon J.: Opt. Pura Apl., 2007, 40, 149.

[15] Moriyama R., Hayashi J., Goda R., Chiba T.: Mater. Chem. Phys., 2005, 92, 205.

https://doi.org/10.1016/j.matchemphys.2005.01.019

[16] Moriyama R., Hayashi J., Suzuki K. et al.: Carbon, 2002, 40, 53. https://doi.org/10.1016/S0008-6223(01)00070-7

[17] Moriyama R., Hayashi J., Chiba T.: Carbon, 2004, 42, 2443. https://doi.org/10.1016/j.carbon.2004.04.044

[18] Kremer H., Cukier S.: J. Microscopy, 1983, 132, 303. https://doi.org/10.1111/j.1365-2818.1983.tb04596.x

[19] Yang Y., Wang C., Chen M., Zheng J.: Fuel Process. Technol., 2011, 92, 154. https://doi.org/10.1016/j.fuproc.2010.08.024

[20] Petrova B., Tsyntsarski B., Budinova T. et al.: Fuel Process. Technol., 2010, 91, 1710.

https://doi.org/10.1016/j.fuproc.2010.07.008

[21] Agarwal R., Bhatia G., Bahl O., Punjabi N.: J. Mater. Sci., 2000, 35, 5437. https://doi.org/10.1023/A:1004871601753

[22] Norfolk C., Kaufmann A., Mukasyan A., Varma A.: Carbon, 2006, 44, 301. https://doi.org/10.1016/j.carbon.2005.07.019

[23] Gao Y., Song H., Chen X.: J. Mater. Sci., 2003, 38, 2209. https://doi.org/10.1023/A:1023740517269

[24] Zhou C., McGinn P.: Carbon, 2006, 44, 1673. https://doi.org/10.1016/j.carbon.2006.01.004

[25] Zhang L., Zhao X., Xia D.: Mater. Lett., 2005, 59, 3448. https://doi.org/10.1016/j.matlet.2004.06.083

[26] Li T., Wang C., Liu X. et al.: Fuel Process. Technol., 2005, 87, 77. https://doi.org/10.1016/j.fuproc.2005.07.003

[27] Liu Z., Guo Q., Song G., Liu L.: Carbon, 2007, 45, 146. https://doi.org/10.1016/j.carbon.2006.07.013

[28] Wang Z., Wu B., Gong Q. et al.: Mater. Lett., 2008, 62, 3585. https://doi.org/10.1016/j.matlet.2008.04.001

[29] Concheso A., Santamaría R,. Menéndez R. et al.: Carbon, 44, 2006, 1762. https://doi.org/10.1016/j.carbon.2005.12.037

[30] Song Z., Li S., Zhai G., Shi J. et al.: Carbon, 2008, 46, 1100. https://doi.org/10.1016/j.carbon.2008.03.018

[31] Menard K.: Thermal Transitions and Their Measurement [in:] Brostow W. (Ed.), Performance of Plastics, Hanser, Munich Cincinnati 2000, Ch. 8.

[32] Brostow W., Hagg Lobland H.: Materials: Introduction and Applications, Wiley, New York 2017.

[33] Lavin-Lopez M., Valverde J., Sanchez-Silva L., Romero A.: Ind. Eng. Chem. Res., 2016, 55, 845. https://doi.org/10.1021/acs.iecr.5b03502

[34] Tertyshna O., Royenko K., Martynenko V. et al.: Chem. Chem. Technol., 2016, 10, 361. https://doi.org/10.23939/chcht10.03.361

[35] Lucas E., Spinelli L.: J. Mater. Ed., 2005, 27, 43.

[36] Middea A., de Mello Monte M., Lucas E.: Chem. Chem. Technol., 2008, 2, 91.

[37] de Melo M., Lucas E.: Chem. Chem. Technol. 2008, 2, 295.

[38] Ramalho J., Ramos N., Lucas E.: Chem. Chem. Technol., 2009, 3, 53.

[39] Lucas E., Mansur C., Spinelli L., Queiros Y.: Pure Appl. Chem., 2009, 81, 473. https://doi.org/10.1351/PAC-CON-08-07-21

[40] Pacheco V., Spinelli L., Lucas E., Mansur C.: Energ. Fuel., 2011, 25, 1659. https://doi.org/10.1021/ef101769e

[41] da Silva C., Barros C., Queiros Y. et al.: Chem. Chem. Technol., 2012, 6, 415. 
[42] Lazorko O., Bratychak M., Pyshev S.: Chem. Chem. Technol., 2008, 4, 309.

[43] Pyshev S., Gunka V., Astakhova O. et al.: Chem. Chem. Technol., 2012, 6, 443.

Received: December 08, 2016/ Revised: December 20, 2016 / Accepted: J anuary 10, 2017

\section{МЕЗОФАЗНІ МІКРОСФЕРИ ПІСЛЯ ДИСТИЛЯЦІї ТА ТЕПЛООБРОБЛЕННЯ КАМ'ЯНОВУГІЛЬНОЇ СМОЛИ}

Анотація. Досліджено утворення мезофазних мікрогранул карбону в пеку, отриманому під час коксування вугілля на сталеплавильному заводі. Пеки отримували за різних температур перегонки (643, 673 i 723 K), після чого їх піддавали термічному обробленню в атмосфері азоту за 723 К протягом 8 год. (T1) або за 703 К протягом 4 год. (Т2). Утворення нової фази підтверджено результатами оптичної мікроскопії з поляризованим фільтром. Встановлено, що зразки після термічного оброблення T1 утворюють рідку дисперсну фазу, відмінну від основної. Утворення мезофазних мікрогранул карбону з діаметром частинок від 30 до 60 мкм доведено для зразків після оброблення Т2. Показано, щз мікрогранули можуть бути використані як вихідні продуктив для синтезу графітових матеріалів.

Ключові слова: мезофазні карбонові мікросфери, кам'яновугільна смола, графітові матеріали. 